\title{
Silicon utilization by sponges: an assessment of seasonal changes
}

\author{
María López-Acosta ${ }^{1}$, Aude Leynaert ${ }^{2}$, Valérie Coquille $^{2}$, Manuel Maldonado $^{1, *}$ \\ ${ }^{1}$ Department of Marine Ecology, Centro de Estudios Avanzados de Blanes (CEAB-CSIC), Blanes 17300, Girona, Spain \\ ${ }^{2}$ Laboratoire des Sciences de l'Environnement Marin, UMR 6539, Institut Universitaire Européen de la Mer, \\ Technopôle Brest-Iroise, Plouzané 29280, France
}

\begin{abstract}
Awareness that sponges are relevant silicic acid (DSi) users is growing; however, understanding how their DSi consumption kinetics perform is still limited. We investigated the effects that seasonal changes in a temperate ecosystem (Bay of Brest, France) have on the DSi consumption of 2 dominant sponge species: Hymeniacidon perlevis and Tethya citrina. The results indicated that while both species increased their rate of DSi utilization with DSi availability following saturable Michaelis-Menten kinetics, only the kinetics of $T$. citrina shifted seasonally. This species consumed DSi at a higher rate in autumn than in summer. Surprisingly, the increase in DSi utilization did not involve an increase in net affinity for DSi but rather augmentation of both the half-saturation concentration and the maximum velocity of transport characterizing the kinetics. By quantifying the biomass of the 2 sponge species in the bay and the monthly availability of DSi over an annual cycle, a yearly DSi consumption of $2.50 \pm 3.21 \times 10^{6} \mathrm{~mol} \mathrm{Si}$ was calculated for their populations. The oversight of the seasonal kinetic change would introduce inaccuracies of $10 \%$ into the global DSi consumption budget of the bay. Because the seasonal kinetic differences increased enormously with increasing DSi availability, the relevance of the kinetic shift into the budgets could increase to $>30 \%$ for sponge assemblages other than those in the bay whenever they are characterized by higher DSi availability, as is typically occurring at high latitudes and in the deep sea.
\end{abstract}

KEY WORDS: Silicic acid · Silicon consumption kinetics $\cdot$ Siliceous sponges $\cdot$ Seasonal variability

\section{INTRODUCTION}

Silicon (Si) is an important element in ocean ecology and biogeochemistry. One of its dissolved forms, silicic acid (DSi), is consumed by a variety of marine organisms such as radiolarians, diatoms, silicoflagellates, choanoflagellates, testate amoebae, cyanobacteria, sponges, and seagrasses (e.g. Armstrong 1965, DeMaster 2003). The consumed DSi is generally used to produce biogenic silica (BSi), an amorphous glasslike substance often used as skeletal material. Diatoms are one of the most relevant Si consumers and, in turn, are one of the ocean's most important primary producers (Nelson et al. 1995, Tréguer et al. 1995). Therefore, it can be said that the DSi availabil-

*Corresponding author: maldonado@ceab.csic.es ity for biological consumption is a major factor in the control of ocean primary productivity. Because of the important implications of DSi availability and its biological utilization, there is an enormous interest in modeling the biological consumption of DSi in the marine environment, at both regional and global scales. For practical and historical reasons, all available global models are based exclusively on the properties of DSi utilization by diatoms, which are the most abundant users (Harriss 1966, Burton \& Liss 1968, Calvert 1968, Nelson et al. 1995, Tréguer et al. 1995, Ragueneau et al. 2000, Laruelle et al. 2009b). However, there are a growing number of studies suggesting that sponges are also relevant $\mathrm{Si}$ users (Rützler \& Macintyre 1978, Conley \& Schelske 1993, Mal-

() The authors 2018. Open Access under Creative Commons by Attribution Licence. Use, distribution and reproduction are unrestricted. Authors and original publication must be credited. 
donado et al. 2005, 2011，2012, Tréguer \& De La Rocha 2013). Although they should also be incorporated into the modeling process, there is still very little known about the kinetics of DSi consumption by sponges. These kinetics have been characterized only for a handful of temperate shallow-water demosponges (Reincke \& Barthel 1997, Maldonado et al. 2011, López-Acosta et al. 2016, 2018). However, no assessment has been made to understand how the large seasonal changes in nutrient and food availability characterizing temperate latitudes affect the patterns of DSi consumption by sponges.

It has long been determined that the seasonal variability in some environmental factors (e.g. inorganic nutrient ratios, seawater temperature, salinity, oxygen distribution) triggers drastic changes in the performance of diatoms, which may increase or decrease their rates of DSi utilization by orders of magnitude in response to those changes (Brzezinski et al. 2008, Hoffmann et al. 2008, Javaheri et al. 2015). Through evolution, sponges are expected to have also evolved their physiology to adapt to the seasonal environmental changes. However, it remains uninvestigated to date whether such seasonal changes actually affect DSi consumption and what the magnitude of such changes, if any, could be. A better understanding of DSi consumption by sponges and the main factors that control the consumption process is required if we are ever to quantify in detail the role of siliceous sponges in the benthic-pelagic coupling of Si cycling at either the regional or global scale.

By combining laboratory experiments and field observations, the present study is, to our knowledge, the first to investigate how seasonality affects the DSi consumption kinetics of temperate sponges and to quantify what the implications are in their natural populations at the ecosystem level.

\section{MATERIALS AND METHODS}

\section{The Bay of Brest as a study case ecosystem}

The Bay of Brest (France; $48.31^{\circ} \mathrm{N}, 4.44^{\circ} \mathrm{W}$ ) is a semi-enclosed marine water body, with an extension of $167.23 \mathrm{~km}^{2}$ (estuaries and harbors excluded), a mean depth of $8 \mathrm{~m}$, and a maximum depth of $45 \mathrm{~m}$. It is connected to the North Atlantic Ocean through a $1.8 \mathrm{~km}$ wide strait, which channels the tidal flow in and out, favoring macrotides of up to $8 \mathrm{~m}$ tidal amplitude. In such a macrotidal system, nearly the entire water mass of the bay is replaced daily (Laruelle et al. 2009a). The bay receives the inflow of 2 rivers that supply important loads of dissolved nutrients and particulate matter with marked seasonal patterns. The local winds are also known to mix most of the vertical water column of the bay daily (Delmas \& Tréguer 1985).

The Bay of Brest has been the subject of numerous ecological, biogeochemical, and physical studies and is currently one of the best-known coastal ecosystems in France, in both structure and functioning (Le Pape et al. 1996, Ragueneau et al. 1996, Del Amo et al. 1997a,b, Chauvaud et al. 2000). Several seawater column parameters of the bay have been monitored weekly at $1 \mathrm{~m}$ depth for decades, and those data are publicly available throughout the Service d'Observation en Milieu Littoral (SOMLIT-Brest: http://somlitdb.epoc.u-bordeaux1.fr/bdd.php). In Fig. 1, monthly averages (mean $\pm \mathrm{SD}$ ) of several basic environmental parameters of the bay are summarized for the last decade (2007-2016): seawater temperature, oxygen concentration, chl $a$, particulate organic carbon (POC), DSi, nitrate, nitrite, ammonium, and phosphate. The system clearly shows a seasonal decrease of all nutrients and oxygen from April to AugustSeptember. Such a decrease starts with the typical spring bloom of phytoplankton (chl a) and is coincidental with the seasonal rise in seawater temperature. From late September to April, nutrients and oxygen increase coincidentally with decreasing seawater temperature. Average values of chl a also decrease slowly from September until the next spring bloom. POC, which may be used as a gross indicator of food availability for sponges, remains relatively unaltered over the annual cycle. In agreement with previous studies (Quéguiner \& Tréguer 1984, Chauvaud et al. 2000), these general trends illustrate that at least 2 distinct environmental and ecological periods occur in the system: (1) spring-summer (AprilSeptember), characterized by progressive increase of temperature and consumption of nutrients and oxygen in the water column; and (2) autumn-winter (October-March), characterized by gradual nutrient and oxygen replenishment and decrease in water temperature and primary productivity.

The Bay of Brest also hosts a rich benthic assemblage of macroalgae and macroinvertebrates, with an abundance of siliceous sponges. The sponge assemblage was recently described and quantified across the 6 habitat-like benthic compartments recognizable in the bay (López-Acosta et al. 2018). A total of 45 siliceous sponge species were identified and quantified, representing an average biomass of $250 \pm 344 \mathrm{ml} \mathrm{m}^{-2}$. Two species, Hymeniacidon per- 


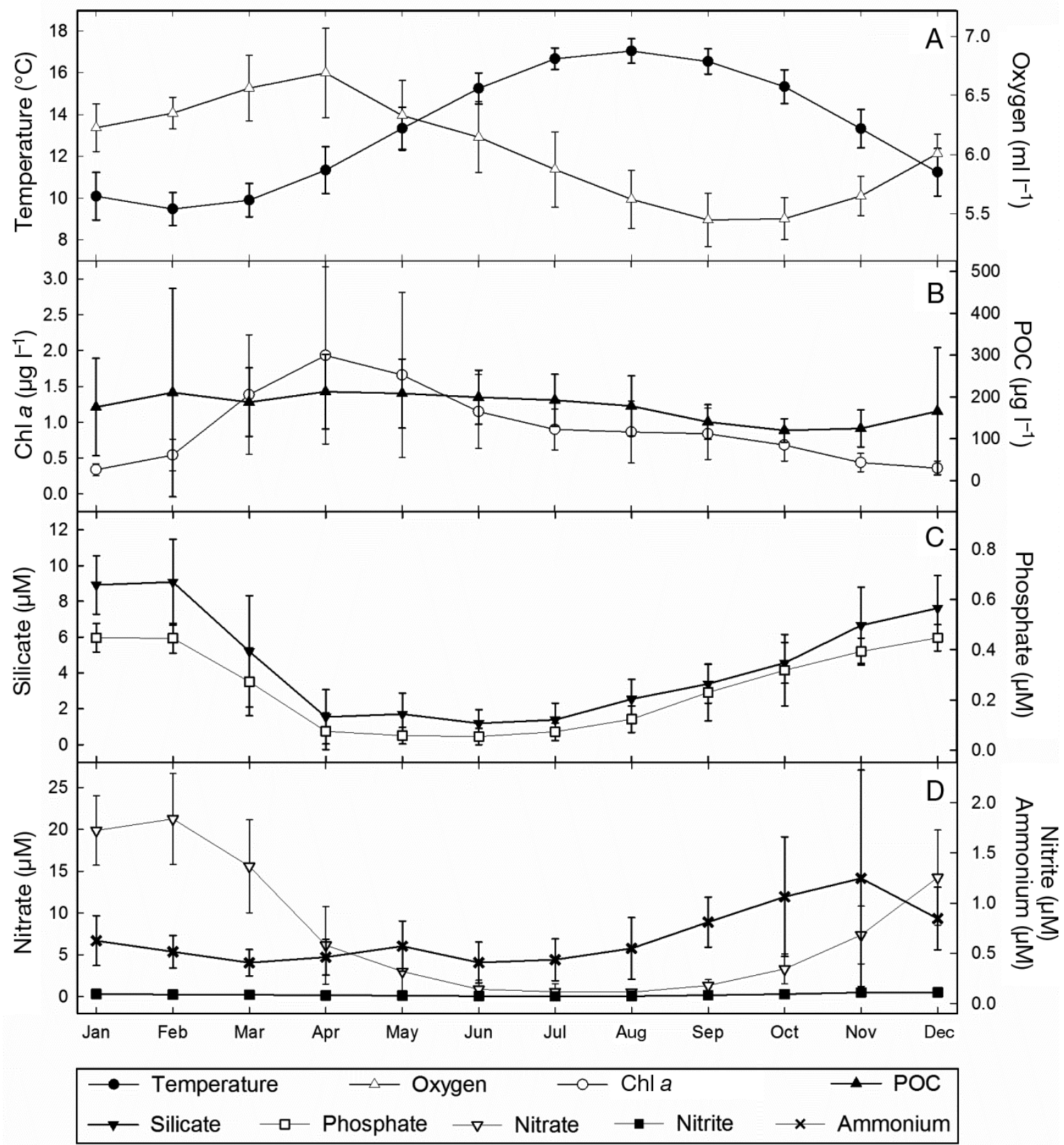

Fig. 1. Monthly averages $( \pm \mathrm{SD})$ of temperature, oxygen concentration, chl $a$, particulate organic carbon (POC), silicate, phosphate, nitrate, nitrite, and ammonium in the Bay of Brest (SOMLIT-Brest station: $48.359^{\circ} \mathrm{N}, 4.552^{\circ} \mathrm{W} ; 1 \mathrm{~m}$ depth) over an annual cycle. Monthly averages result from weekly measurements taken over a decade (2007-2016)

levis (Montagu, 1814) and Tethya citrina Sarà \& Melone, 1965, were dominant in biomass $(99.94 \pm 122.20$ and $32.67 \pm 45.07 \mathrm{ml} \mathrm{m}^{-2}$, respectively), accounting collectively for $53.1 \%$ of the sponge standing stock of the bay (López-Acosta et al. 2018).

Those 2 dominant sponge species were selected for the present study in order to examine both the effects of seasonality on their DSi consumption kinetics and the implications of those effects at the population level in the bay.

\section{Experimental setup}

To assess whether the factor season has an effect on how $H$. perlevis and T. citrina consume DSi, we investigated their DSi utilization in summer (July 2015), when natural DSi availability is low, and in autumn (October-November 2016), when DSi replenishment starts. The underlying hypothesis is that through evolution, the sponges may have adapted their physiology (e.g. skeletal growth) to process DSi 
with more avidity (i.e. transport affinity) at the time of the year when its natural availability starts increasing. Because the silicification process in sponges is mediated by enzymes (Shimizu et al. 1998, Krasko et al. 2000), such a change in the affinity of the sponges by the substrate (DSi) may have a profound impact on the kinetics of DSi consumption. Also, these 2 sponge species show a contrasting level of skeletonization, with the siliceous skeleton of $H$. perlevis representing about $45 \pm 4 \%$ of the dry weight of the individuals and that of $T$. citrina about $63 \pm 5 \%$ (López-Acosta et al. 2016). Such skeletal differences suggest that both species may also differ in their specific needs for DSi when building their respective skeletons.

Following the methodology detailed in LópezAcosta et al. (2016), we conducted 2 experiments (one in summer, the other in autumn) for characterizing the respective kinetics of DSi consumption. In each experiment, DSi consumption was investigated in 9 individuals of $H$. perlevis and 8 of $T$. citrina, along with a set of 6 controls (see next paragraph).

During the experiments, each sponge was placed into an aquarium filled with $2.78 \pm 0.121$ of $1 \mu \mathrm{m}$ filtered seawater from the Bay of Brest and incubated for a succession of $72 \mathrm{~h}$ periods under increasing DSi concentrations. The experiments started with DSi concentrations of $2 \mu \mathrm{M}$ in summer and $4 \mu \mathrm{M}$ in autumn, which corresponded to the field values at the onset of the experiment. Concentrations were then progressively increased to $75,150,200$, and $250 \mu \mathrm{M}$ in both experiments (see Supplement 1 at www.int-res.com/articles/suppl/m605p111_supp.pdf for slight deviations between intended and assayed DSi concentrations in each experiment). To determine DSi utilization during every $72 \mathrm{~h}$ incubation, each aquarium was sampled at the beginning and end of each incubation period by collecting $20 \mathrm{ml}$ of seawater with plastic syringes. Consumption of DSi by each sponge at a given DSi concentration step was inferred from the difference in DSi concentration between the beginning and end of the incubation period, after correcting by the average concentration changes that occurred in the control aquaria, which consistently were nearly zero. The controls consisted of 3 aquaria that were filled with only seawater and 3 other aquaria that were each filled with seawater and a piece of maërl similar to that often used by sponges as substrate.

Water samples for determining DSi concentration were filtered with $0.22 \mu \mathrm{m}$ pore size polycarbonate syringe filters (Millex-GS, Millipore) and stored in the refrigerator for only 1 to $4 \mathrm{~d}$ prior to analysis. The seawater samples from the initial and final times of each incubation were always analyzed in a single batch to minimize methodological variability. DSi determination was carried out by spectrophotometric analysis following the standard colorimetric method (Strickland \& Parsons 1972), with a determination precision of $5 \%$. Samples from DSi concentrations higher than $30 \mu \mathrm{M}$ were diluted prior to analysis.

Immediately after each experiment, we measured several morphometric parameters of the assayed individuals - volume $(\mathrm{ml})$, wet weight $(\mathrm{g})$, constant dry weight $(g)$, and ash-free weight $(g)$ - which served for normalizing DSi consumption rates. Preferentially, DSi consumption was normalized by volume of seawater in the aquarium (l), time unit (h), and volume of the assayed sponge (ml). Normalization by sponge volume was preferred because it facilitates future extrapolation to field sponge populations without the need for conducting destructive sampling by just measuring the sponges in vivo through rulers or photogrammetically (Abdo et al. 2006, Maldonado et al. 2010).

Irrespective of normalizing DSi consumption by morphometric parameters, for each species, we intended the body size range of the assayed individuals for each season to differ minimally. In both seasons, the individuals of $H$. perlevis ranged similarly in volume from 1.5 to $16.5 \mathrm{ml}$ and those of $T$. citrina from 2.8 to $16 \mathrm{ml}$. The selected size ranges for these species represent the small and mean portions of their natural body size range. Very large individuals of both species were deliberately excluded because of logistic constraints for optimal maintenance of such large animals in the relatively small aquaria required for the experiments (see Supplement 2 at www.intres.com/articles/suppl/m605p111_supp.pdf).

\section{Testing for seasonality in DSi consumption}

Recent investigations in $H$. perlevis and T. citrina reported that DSi consumption kinetics fit a MichaelisMenten function (López-Acosta et al. 2016). Consequently, we used non-linear goodness of fit analysis to model the DSi consumption rate as a function of increasing DSi availability to the sponges. To examine the effect of seasonality on the DSi consumption rates for each species, we carried out 3 complementary statistical approaches. In the first approach, we used a 2-factor design because the experiment involved determination of DSi consumption rates as a function of both the season of the year (summer versus autumn) and the availability of DSi $(3,75,150$, 
200, and $250 \mu \mathrm{M} \mathrm{DSi}$ ). For each season, the same sponges were exposed to increasing DSi concentrations throughout the experiment, but the individuals assayed in July's experiment were different from those used in October-November. Therefore, the 2factor design involves a component of repeated measures nested within the factor season. Because consumption rates of both species failed the normality test (Shapiro-Wilks test) and transformations were unable to modify that condition, we approached the 2 -way repeated measurement test by using the ANOVA-type statistic (ATS) (Brunner et al. 2002) separately for each sponge species. Untransformed DSi consumption rate data were analyzed by the ATS test using the package nparLD (Noguchi et al. 2012) in $\mathrm{R}$ version 3.4.2 (Supplement 3 at www.int-res.com/ articles/suppl/m605p111_supp.pdf). A posteriori pairwise comparisons based on Brunner-Munzel tests (Brunner \& Munzel 2000) were run using the package lawstat in R version 3.4.2 (Supplement 3).

In the second approach, we evaluated betweenseason differences in the total DSi consumption accumulated by each sponge species during the entire experiment (15 d). Between-season differences in the mean DSi consumed were examined separately for each species using a $t$-test on untransformed normally distributed data. In the third approach, we examined differences between the kinetic parameters that govern the model equations describing DSi consumption in summer and autumn for each species. We first estimated the Michaelis-Menten model for each assayed individual, obtaining the maximum velocity of transport $\left(V_{\max }\right)$ and half-saturation constant $\left(K_{\mathrm{m}}\right)$ for each individual of each species during each season. We then examined, separately for each species, between-season differences in the average values of $K_{\mathrm{m}}$ and $V_{\max }$ parameters using the $t$-test on untransformed data, if they were normal and homoscedastic. When data did not meet either normality (Shapiro-Wilks test) or homoscedasticity (BrownForsythe test), the non-parametric Mann-Whitney $U$ test was conducted to examine the significance of between-season differences in the mean values.

\section{Between-individual variability}

In previous studies on DSi utilization by sponges, body size was identified as a source of between-individual variability in the DSi utilization rate (Maldonado et al. 2011, López-Acosta et al. 2016). Therefore, we used regression analysis to examine the relationship between the body size (in $\mathrm{ml}$ ) of an in- dividual and the $V_{\max }$ that it achieved during the experiment (irrespective of the DSi concentration step at which that $V_{\max }$ was achieved). For this regression, we considered a total of 34 individuals of $H$. perlevis and 33 of $T$. citrina. This set of individuals consisted of all the individuals (18 of $H$. perlevis and 16 of T. citrina) used to determine DSi consumption kinetics along with an additional 16 and 17 individuals of $H$. perlevis and T. citrina, respectively, which were similarly exposed to increasing DSi concentrations. The addition of these new individuals was considered necessary to appropriately investigate between-individual variability, since it allowed for a wider range in body size, i.e. a range more similar to the one occurring in the natural population. For both species, the body size of the assayed individuals ranged from 1 to $30 \mathrm{ml}$ in volume. Because in T. citrina the reproductive status had also been identified as a source of between-individual variability in DSi consumption responses (López-Acosta et al. 2016), a discrimination between asexually reproductive and non-reproductive individuals was made in the regression analyses and the potential effects of this condition examined.

\section{DSi consumption in wild populations}

To estimate daily and yearly rates of DSi consumption in the bay by the natural populations of $H$. perlevis and T. citrina, 3 sources of data were used: (1) the natural variability of DSi concentrations in the Bay of Brest over the last decade (2007-2016; Fig. 1), which was averaged monthly over an ideal annual cycle $_{i}(2)$ the mean abundance $\left(\mathrm{ml} \mathrm{m}^{-2}\right)$ of the selected species (H. perlevis, $99.94 \pm 122.20 \mathrm{ml} \mathrm{m}^{-2} ; \mathrm{T}$. citrina, $32.67 \pm 45.07 \mathrm{ml} \mathrm{m}^{-2}$ ) in the natural populations (López-Acosta et al. 2018); and (3) the herein-determined between-season differences in the kinetics of DSi consumption by the 2 concerned species. The consumption of DSi by the biomass of each species was calculated as a function of the monthly change in DSi concentration in the seawater, also incorporating the corresponding species-specific kinetic shifts.

\section{RESULTS}

\section{DSi consumption kinetics}

The 2 sponge species reacted similarly to the increase in DSi availability in both seasons: the mean rate of DSi consumption rose with increasing DSi 
availability until reaching a certain saturating concentration (Fig. 2). When these responses were modeled mathematically, the best significant model retrieved by goodness of fit for both sponges in the 2 seasons was consistently a saturable MichaelisMenten model (Fig. 3). Both the experimental data and the models suggested that the consumption rates rise with increasing DSi availability until concentrations of 150 to $200 \mu \mathrm{M} \mathrm{DSi}$, values at which DSi consumption by the sponges appeared to reach satura-

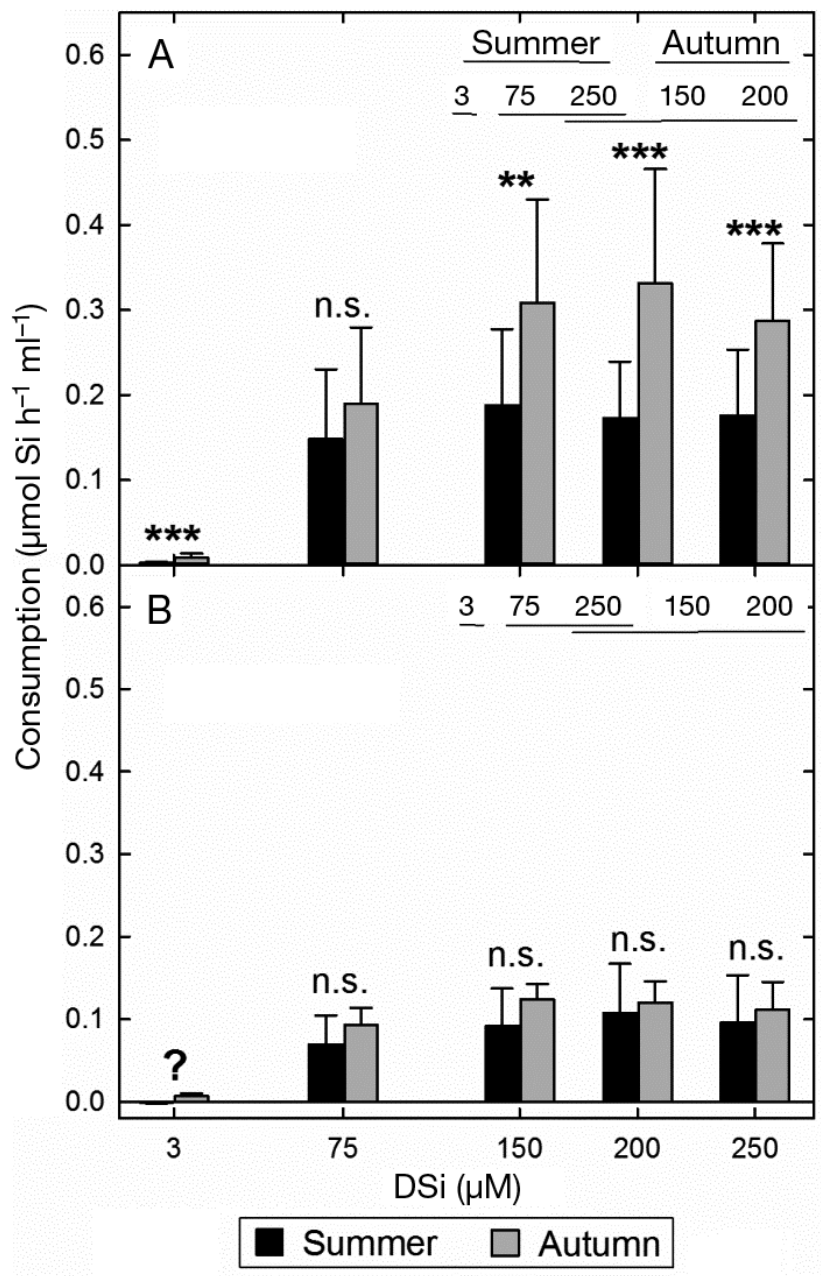

Fig. 2. Average $( \pm \mathrm{SD})$ silicic acid $(\mathrm{DSi})$ consumption rates measured as a function of DSi availability during summer and autumn experiments in (A) Tethya citrina and (B) Hymeniacidon perlevis. In the right upper corner of each graph, the levels of the significant factors following an ANOVA-type statistic bifactorial test are given. Levels are ordered from left to right by increasing magnitude of their average value. Levels of a factor underlined by the same line are not significantly different from each other. The statistical significance of the pairwise tests examining differences in the consumption rate between summer and autumn at each DSi concentration step is indicated as follows: ${ }^{* *} \mathrm{p}<0.01$; ${ }^{* * *} \mathrm{p}<0.001$; n.s.: not significant; ?: rates below analytical detection tion (Fig. 2). These saturating DSi concentrations are 1 to 2 orders of magnitude higher than those naturally occurring in the sponge habitats over the annual cycle (Fig. 1C). Consequently, the skeletal growth of the 2 assayed species can be said to be chronically limited by a natural shortage of DSi.

Although both species followed the same general kinetic model in the 2 seasons (Fig. 3), all 4 resulting kinetics did not always have similar values for their kinetic parameters, i.e. the maximum velocity of transport $\left(V_{\max }\right)$ and the half-saturation constant $\left(K_{\mathrm{m}}\right)$. The $V_{\max }$ characterizing the kinetic models of Hymeniacidon perlevis in summer and autumn were relatively similar $(0.131 \pm 0.018$ and $0.142 \pm 0.017 \mu \mathrm{mol}$ $\mathrm{Si} \mathrm{h}^{-1} \mathrm{ml}^{-1}$ sponge, respectively), suggesting that seasonal differences, if any, must be small. In contrast, in Tethya citrina, the $V_{\max }$ in autumn $(0.429 \pm$ $0.101 \mu \mathrm{mol} \mathrm{Si} \mathrm{h}{ }^{-1} \mathrm{ml}^{-1}$ sponge) was more than twice that in summer $\left(0.206 \pm 0.020 \mu \mathrm{mol} \mathrm{Si} \mathrm{h}{ }^{-1} \mathrm{ml}^{-1}\right.$ sponge; Fig. 3A,B), suggesting seasonal effects. The inspection of $K_{\mathrm{m}}$ indicated values that were about 2 times larger in autumn than in summer for both species (Fig. 3A,B). Whether these numerical differences in the parameters involve statistically significant differences in the kinetics of DSi utilization will be addressed in the next section.

\section{Seasonal variability in DSi consumption}

The results of statistical approach 1 for each sponge species, based on a bifactorial ATS, are summarized in Fig. 2 and Table 1. For T. citrina (Fig. 2A), the factor season was found to have a significant effect on consumption rates, with sponges consuming DSi at an average rate that was $99.5 \pm 87.1 \%$ higher in autumn than in summer, when all DSi concentration steps for each season were pooled. The factor DSi availability also had a significant effect, increasing $\mathrm{DSi}$ consumption with increasing $\mathrm{DSi}$ availability up to a threshold concentration (Fig. 2A, Table 1). The a posteriori tests confirmed that such a DSi saturating threshold was the $150 \mu \mathrm{M}$ step (Fig. 2A). The ATS also detected a significant interaction between the 2 main factors (Table 1). The $a$ posteriori pairwise comparisons revealed that the interaction was because DSi consumption rates were significantly larger in autumn than in summer at all the investigated DSi concentrations, but at the $75 \mu \mathrm{M}$ step (Fig. 2A). For $H$. perlevis, the ATS statistic revealed that only the factor DSi availability had a significant effect on consumption rate, and the pairwise a posteriori tests indicated that the consumption 

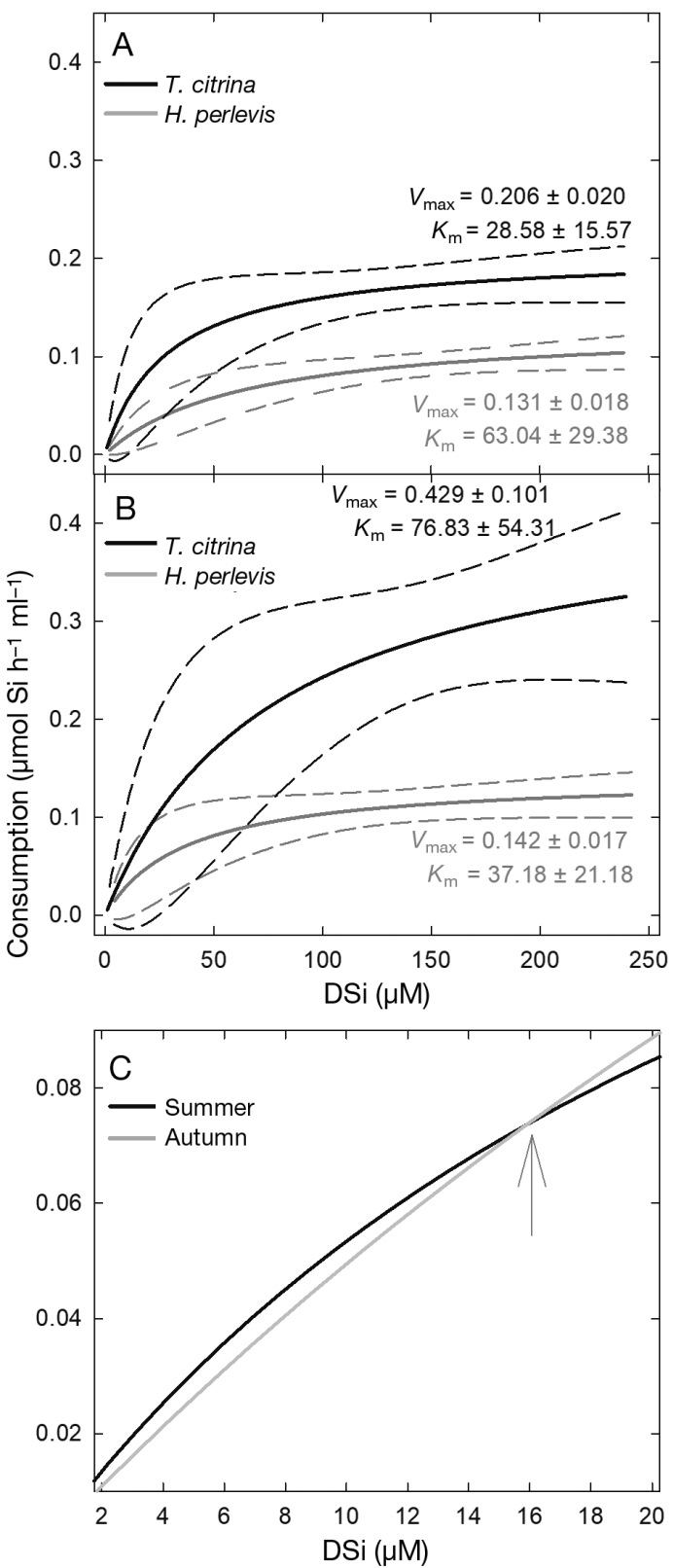

Fig. 3. Silicic acid (DSi) consumption kinetics estimated by goodness of fit for the sponges Tethya citrina and Hymeniacidon perlevis during the experiments in (A) summer and (B) autumn. In all 4 cases, consumption kinetics significantly fit a saturable Michaelis-Menten model in the form DSi consumption $=V_{\max } \times[\mathrm{DSi}] /\left(K_{\mathrm{m}}+[\mathrm{DSi}]\right)$, with the maximum velocity of DSi transport $\left(V_{\max }\right)$ and half-saturation $\left(K_{\mathrm{m}}\right)$ values of each equation given in the figure. The statistics of the goodness of fit analyses for $H$. perlevis were $\mathrm{r}^{2}=0.98, \mathrm{p}=$ 0.001 in summer and $\mathrm{r}^{2}=0.97, \mathrm{p}=0.002$ in autumn. For T. citrina, they were $\mathrm{r}^{2}=0.98, \mathrm{p}=0.001$ in summer and $\mathrm{r}^{2}=0.95$, $\mathrm{p}=0.006$ in autumn. Solid and dashed lines refer to the regression line and the $95 \%$ confidence band, respectively. (C) Detail of both the summer and autumn DSi consumption kinetic models of $T$. citrina at the DSi concentrations occurring in the Bay of Brest, i.e. 1 to $20 \mu \mathrm{M}$. The arrow indicates the DSi concentration threshold $(15 \mu \mathrm{M})$ at which summer and autumn DSi consumption kinetic models intersect in T. citrina rate increased with DSi availability up to a concentration of $150 \mu \mathrm{M}$ DSi (Table 1, Fig. 2B), in agreement with the saturating threshold value identified for $T$. citrina.

Statistical approach 2 revealed that the total amount of DSi consumed by T. citrina during the $15 \mathrm{~d}$ of the autumn experiment $(78.29 \pm 29.19 \mu \mathrm{mol} \mathrm{Si}$ $\mathrm{ml}^{-1}$ ) was significantly higher than that of the summer experiment $\left(47.57 \pm 21.04 \mu \mathrm{mol} \mathrm{Si} \mathrm{ml}{ }^{-1} ; F=-2.4\right.$, $\mathrm{df}=14, \mathrm{p}=0.030)$. However, $H$. perlevis did not show significant between-season differences (31.76 $\pm 5.32 \mu \mathrm{mol} \mathrm{Si} \mathrm{ml} \mathrm{m}^{-1}$ in autumn versus $25.18 \pm$ $13.13 \mu \mathrm{mol} \mathrm{Si} \mathrm{ml} \mathrm{m}^{-1}$ in summer; $F=-1.4$, df $=16, \mathrm{p}=$ 0.183). Therefore, the results of these $t$-tests (approach 2) come into full agreement with those of the ATS (approach 1), supporting a seasonal effect on DSi utilization in $T$. citrina but not in $H$. perlevis.

Statistical approach 3 indicated that in T. citrina, there were significant between-season differences in both the $V_{\max }\left(0.229 \pm 0.102 \mu \mathrm{mol} \mathrm{Si} \mathrm{h}{ }^{-1} \mathrm{ml}^{-1}\right.$ in summer versus $0.464 \pm 0.169 \mu \mathrm{mol} \mathrm{Si} \mathrm{h} \mathrm{ml}^{-1}$ in autumn; $t=-3.4, \mathrm{df}=14, \mathrm{p}=0.005)$ and the $K_{\mathrm{m}}$ parameters of the kinetics $(49.83 \pm 34.97 \mu \mathrm{M}$ in summer versus 98.56 $\pm 51.44 \mu \mathrm{M}$ in autumn; $t=-2.2, \mathrm{df}=14, \mathrm{p}=0.044)$. However, in $H$. perlevis, there was no significant between-season difference in either the $V_{\max }(0.127 \pm$ $0.091 \mu \mathrm{mol} \mathrm{Si} \mathrm{h}{ }^{-1} \mathrm{ml}^{-1}$ in summer versus $0.145 \pm$ $0.122 \mu \mathrm{mol} \mathrm{Si} \mathrm{h} \mathrm{ml}^{-1}$ in autumn; $U=32, \mathrm{p}=0.480$ ) or the $K_{\mathrm{m}}(77.07 \pm 49.53 \mu \mathrm{M}$ in summer versus $50.14 \pm$ $36.36 \mu \mathrm{M}$ in autumn; $t=1.3, \mathrm{df}=16, \mathrm{p}=0.207$ ).

Together, the 3 statistical approaches fully agree in concluding that seasonality significantly affects DSi consumption in $T$. citrina but not in $H$. perlevis. Interestingly, in T. citrina, the kinetic differences between seasons increase with increasing DSi availability (Fig. 3). Such a pattern is not trivial, because it means that the implications of seasonal kinetic changes will be minor for $T$. citrina populations established in

Table 1. Summary of the 2-factor ANOVA-type statistic tests analyzing differences in consumption rates as a function of season and silicic acid (DSi) availability in Tethya citrina and Hymeniacidon perlevis

\begin{tabular}{|lrrr|}
\hline Factor & Statistic & df & p-value \\
\hline T. citrina & & & \\
Season & 7.2 & 1.0 & 0.007 \\
DSi & 105.3 & 2.0 & $<0.001$ \\
Season $\times$ DSi & 4.4 & 2.0 & 0.012 \\
H. perlevis & & & \\
Season & 3.6 & 1.0 & 0.058 \\
DSi & 55.1 & 2.6 & $<0.001$ \\
Season $\times$ DSi & 0.4 & 2.6 & 0.698 \\
\hline
\end{tabular}


environments permanently characterized by low DSi concentrations but of noticeable relevance in habitats with DSi concentrations above $50 \mu \mathrm{M}$. At the DSi concentrations that characterized the Bay of Brest (0.01-15 $\mu \mathrm{M} \mathrm{DSi})$, the summer kinetics of $T$. citrina resulted in DSi consumption rates that are slightly higher than those that resulted from the autumn kinetics (Fig. 3C). The opposite pattern is observed when DSi concentration is higher than $15 \mu \mathrm{M}$ (Fig. 3C), the DSi level from which DSi consumption rates in $T$. citrina are higher in autumn than in summer (Fig. 3). This result indicates that the species $T$. citrina has mechanisms (still unknown) to increase consumption when DSi availability is extremely low, as occurs in summer at the Bay of Brest (see Fig. 1).

Because between-season differences do not appear to exist in $H$. perlevis, the global DSi consumption kinetics for this species over the annual cycle was better calculated by pooling the responses of all assayed individuals in summer and autumn $(\mathrm{n}=18)$. The resulting kinetic equation $\left(\mathrm{r}^{2}=0.92, \mathrm{p}<0.001\right)$, characterized by a $V_{\max }$ of $0.134 \pm 0.018 \mu \mathrm{mol} \mathrm{Si} \mathrm{h}{ }^{-1}$ $\mathrm{ml}^{-1}$ and a $K_{\mathrm{m}}$ of $45.30 \pm 25.07 \mu \mathrm{M}$, is an equation line (not depicted) that would lie in between the 2 seasonal ones depicted in Fig. 3A,B.

\section{Between-individual variability}

When Si consumption responses of each assayed individual were inspected, considerable betweenindividual variability was noticed within each species (Fig. 4), being consistently of larger magnitude in T. citrina (Fig. 4A,B) than in H. perlevis (Fig. 4C,D). Although the range of inter-individual variability in DSi consumption over the entire course of these experiments is difficult to measure comparatively, some analyses were attempted. For those, we examined differences in the maximum rate of DSi consumption (i.e. empirical $V_{\max }$ ) reached by the individuals during an experiment, irrespective of the DSi concentration step at which such $V_{\max }$ was attained. For instance, in T. citrina in summer (Fig. 4A), the individuals spanned a range in the rate of maximum DSi consumption that varied from $0.121 \mu \mathrm{mol} \mathrm{Si} \mathrm{h}{ }^{-1}$ $\mathrm{ml}^{-1}$ (achieved by Ind. 4 at $200 \mu \mathrm{M}$ DSi) to $0.387 \mu \mathrm{mol}$ $\mathrm{Si} \mathrm{h}^{-1} \mathrm{ml}^{-1}$ (achieved by Ind. 6 at $150 \mu \mathrm{M} \mathrm{DSi}$ ). In autumn (Fig. 4B), they ranged from $0.190 \mu \mathrm{mol} \mathrm{Si} \mathrm{h}^{-1}$ $\mathrm{ml}^{-1}$ (achieved by Ind. 4 at $200 \mu \mathrm{M}$ DSi) to $0.577 \mu \mathrm{mol}$ $\mathrm{Si} \mathrm{h}^{-1} \mathrm{ml}^{-1}$ (achieved by Ind. 7 at $200 \mu \mathrm{M}$ DSi). In summary, although $V_{\max }$ values were consistently higher in autumn than in summer in T. citrina, the

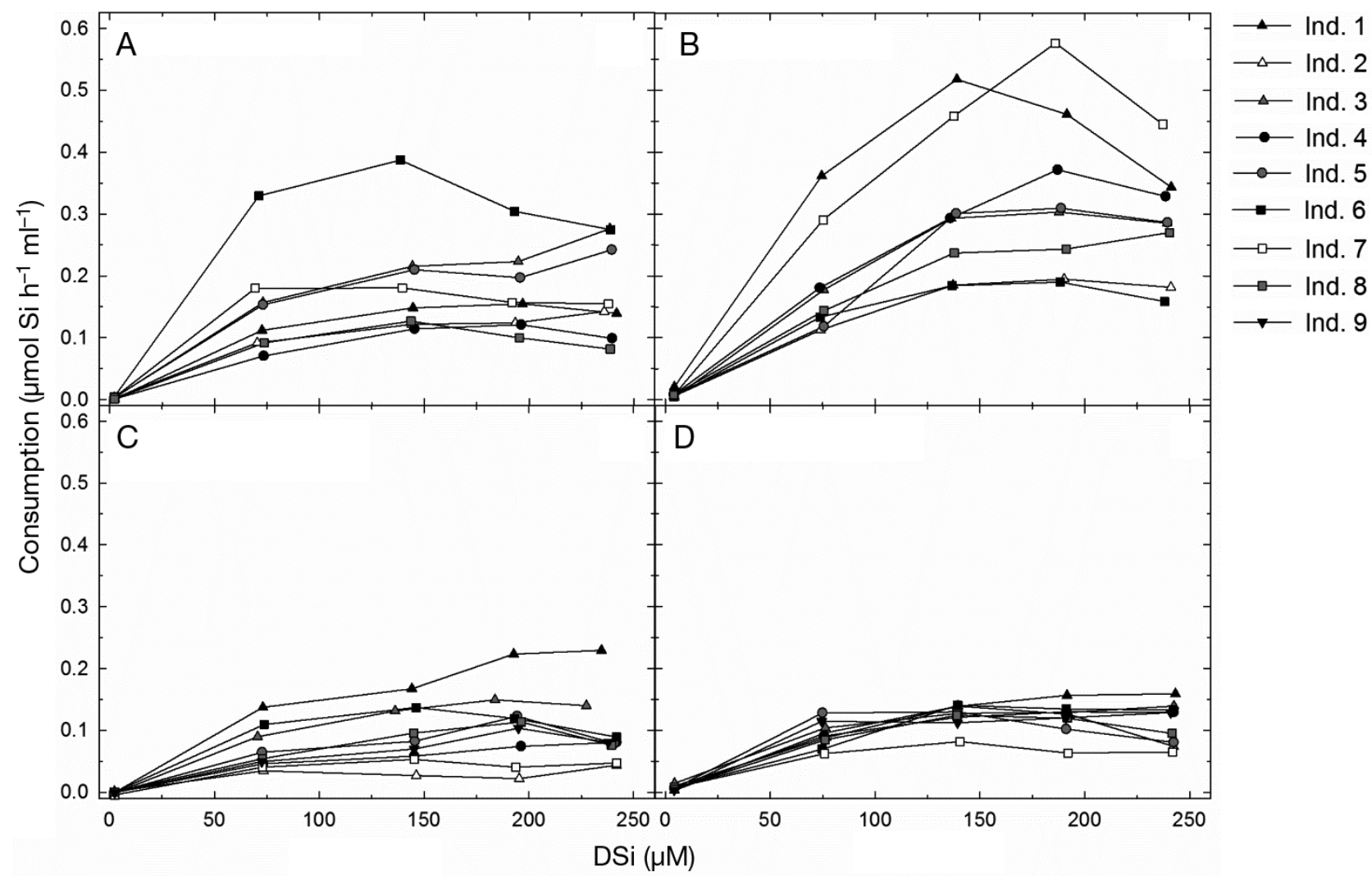

Fig. 4. Consumption rates as a function of silicic acid (DSi) concentration of each assayed individual of (A,B) Tethya citrina and $(\mathrm{C}, \mathrm{D})$ Hymeniacidon perlevis during $(\mathrm{A}, \mathrm{C})$ summer and $(\mathrm{B}, \mathrm{D})$ autumn experiments 
range of between-individual variability was similar across seasons, the largest values being around 3fold higher than the lowest ones, irrespective of season. Unlike in T. citrina, the range of DSi consumption rate in $H$. perlevis appeared to be higher in summer (Fig. 4C) than in autumn (Fig. 4D). In this case, the range spanned between the lowest and the highest values of $V_{\max }$ in summer $(0.044$ and $0.229 \mu \mathrm{mol} \mathrm{Si} \mathrm{h}{ }^{-1} \mathrm{ml}^{-1}$ achieved by Inds. 2 and 1, respectively, at the $250 \mu \mathrm{M}$ DSi step) was more than 2 -fold that recorded in autumn $(0.082$ and $0.159 \mu \mathrm{mol}$ $\mathrm{Si} \mathrm{h}^{-1} \mathrm{ml}^{-1}$ by Inds. 7 and 1 at 150 and $250 \mu \mathrm{M} \mathrm{DSi}$, respectively).

The regression analyses indicated that part of this variability in the normalized consumption rate is due to size differences between the individuals (Fig. 5). A significant - though weak - inverted, non-linear relationship was found between sponge size (in $\mathrm{ml}$ ) and the maximum velocity of DSi consumption ( $V_{\max }$, i.e. the maximum velocity of DSi transport empirically determined, which has been achieved at saturating DSi concentrations) in both $T$. citrina $\left(\mathrm{n}=33, \mathrm{r}^{2}=\right.$ $0.24, \mathrm{p}=0.004$; Fig. 5A) and H. perlevis $\left(\mathrm{n}=34, \mathrm{r}^{2}=\right.$ $0.12, \mathrm{p}=0.040$; Fig. 5B). Typically, the highest $V_{\max }$ was achieved by the smallest individuals. This pattern was not surprising because the smaller an individual, the more incomplete its skeletal growth and, therefore, the greater its DSi needs to complete the siliceous skeleton.

In the species T. citrina, the individuals that were budding asexually were also the biggest sponges (Fig. 5A); therefore, size and asexual reproduction became confounding factors, and the significance of the latter in the DSi consumption process, if any, was unable to emerge clearly from our approach.

\section{DSi consumption in wild populations}

At the Bay of Brest (France), both H. perlevis and T. citrina are abundant species, with an average biomass of $99.94 \pm 122.20$ and $32.67 \pm 45.07 \mathrm{ml} \mathrm{m}^{-2}$, respectively. The decadal trend in DSi concentration in the bay indicates large monthly shifts (Fig. 1), ranging from average minima of $1.2 \pm 0.8 \mu \mathrm{M}$ (in June) to average maxima of $9.1 \pm 2.4 \mu \mathrm{M}$ (in February). However, there may be transient weekly peaks of up to $20 \mu \mathrm{M}$ from December to February, depending on year. Our kinetic models indicate that these changes impact monthly DSi utilization rates by both sponges, but more on T. citrina. The effects of accommodating not only the monthly shifts in DSi availability but also the seasonal kinetic shift in DSi

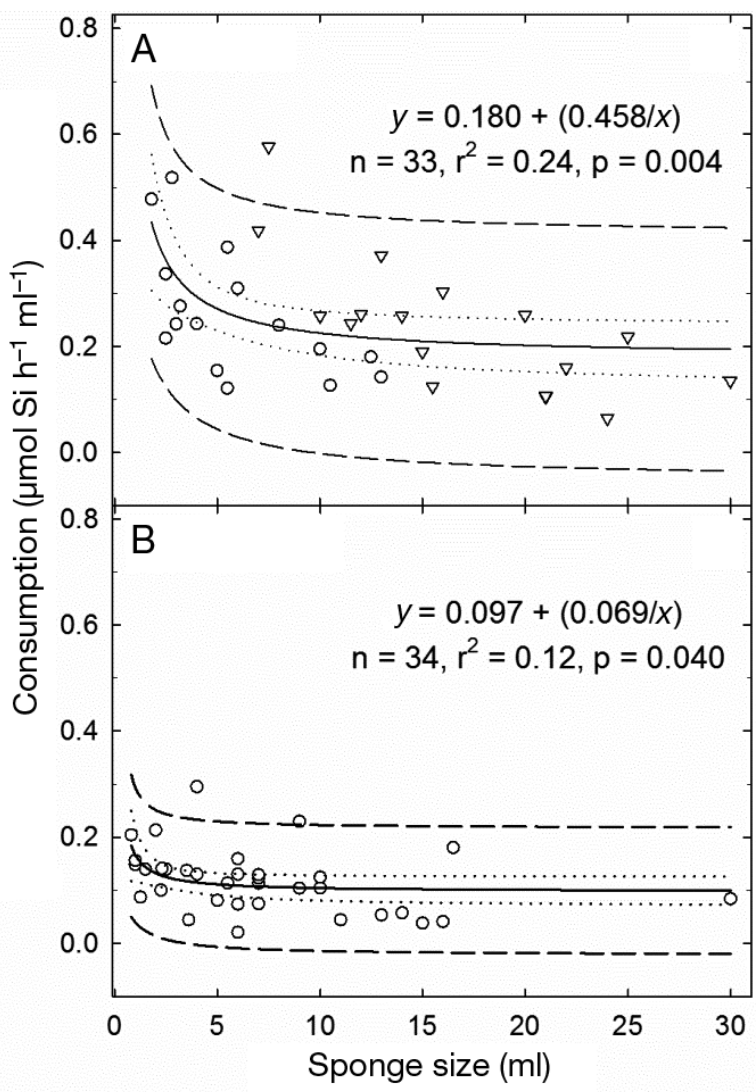

Fig. 5. Relationship between sponge size and maximum silicic acid (DSi) consumption rate calculated for a set of (A) 33 Tethya citrina individuals and (B) 34 Hymeniacidon perlevis individuals. The size range spanned by the assayed individuals is representative of that occurring in the wild population. In T. citrina (A), those individuals that were engaged in the production of buds for asexual reproduction are indicated by inverted triangles. Dotted and dashed lines refer to the $95 \%$ confidence band and the $95 \%$ prediction band of the regression equations, respectively

consumption detected for $T$. citrina are summarized in Fig. 6.

Our kinetic modelling predicts that in February, when DSi availability is at a maximum, both sponges show their highest DSi consumption rate $(53.65 \pm$ $65.60 \mu \mathrm{mol} \mathrm{Si} \mathrm{m}{ }^{-2} \mathrm{~d}^{-1}$ in $H$. perlevis and $35.54 \pm$ $49.03 \mu \mathrm{mol} \mathrm{Si} \mathrm{m}{ }^{-2} \mathrm{~d}^{-1}$ in T. citrina; Fig. 6). However, when DSi concentration decreases to its annual minimum in June, $H$. perlevis and $T$. citrina are predicted to consume DSi at a rate about 6 times lower $(8.24 \pm$ 10.08 and $6.47 \pm 8.92 \mu \mathrm{mol} \mathrm{Si} \mathrm{m}{ }^{-2} \mathrm{~d}^{-1}$, respectively) than that in February (Fig. 6). By considering the monthly shifts in DSi availability and the seasonal kinetic adaptation uncovered in T. citrina, we have estimated that the populations of $H$. perlevis and $T$. citrina consume annually $1.48 \pm 1.81$ and $1.01 \pm$ $1.40 \times 10^{6} \mathrm{~mol} \mathrm{Si}$, respectively. Collectively, they total 


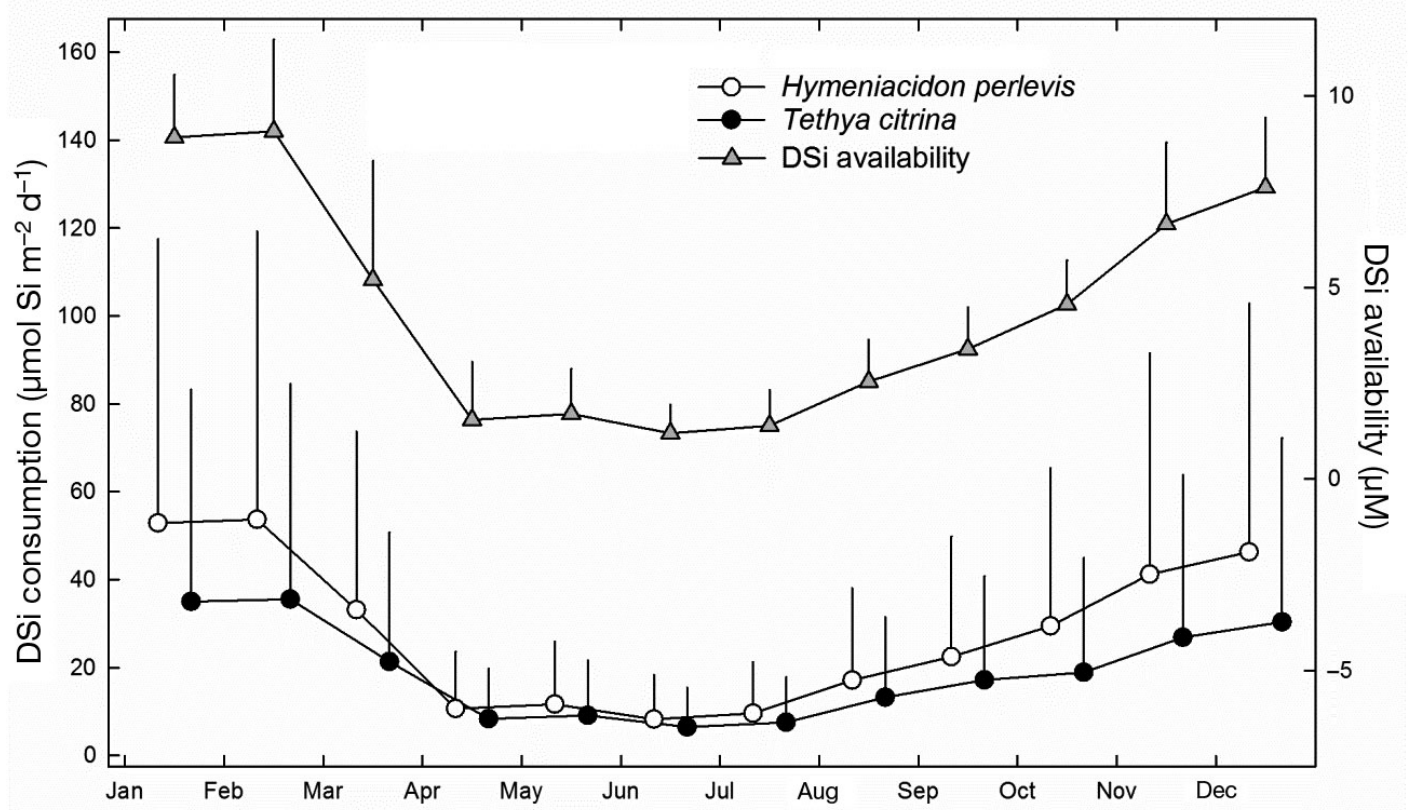

Fig. 6. Monthly averages $( \pm \mathrm{SD})$ of silicic acid (DSi) consumption rate by the population of Hymeniacidon perlevis and Tethya citrina in the Bay of Brest over an annual cycle. Monthly averages ( \pm SD) of DSi availability in the water of the bay are also indicated. Only positive standard deviations are depicted

$2.50 \pm 3.21 \times 10^{6} \mathrm{~mol}$ Si. This DSi utilization had never been considered before at the local Si budget of the bay (e.g. Ragueneau et al. 2005).

It remains unknown how many species of the bay experience seasonal changes in their DSi consumption kinetics (as in T. citrina) and how many do not (as in H. perlevis). If many species are affected seasonally, their collective effect on the global Si budget of the bay can be substantial. For instance, by neglecting the seasonal shift in the kinetics of T. citrina and considering only the autumn response for the calculations, we would be underestimating the $\mathrm{Si}$ consumed by the population in the bay in about $5.1 \%$

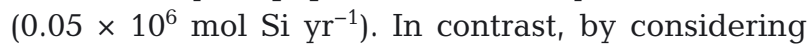
only the summer kinetics, we would be overestimating DSi utilization by the population in $9.2 \%(0.09 \times$ $10^{6} \mathrm{~mol} \mathrm{Si} \mathrm{yr}^{-1}$ ).

Another aspect worth mentioning is that the divergence between the summer and autumn models in T. citrina shown in Fig. 3 reveals that the impact of the seasonal differences would become greater when the environmental DSi availability rises higher than $30 \mu \mathrm{M}$. This is not expected to have many consequences in the Bay of Brest, since DSi would rarely peak over $25 \mu \mathrm{M}$ and only for a few days a year, if at all. However, if similar kinetic shifts occur in species inhabiting DSi-rich environments, their effects on the local budget could be substantial (see 'Discussion').

\section{DISCUSSION}

The DSi consumption kinetics of Hymeniacidon perlevis and Tethya citrina fit a saturable MichaelisMenten model irrespective of the season (Fig. 3). This pattern is consistent with that shown by all investigated sponges to date. Saturation of the DSi consumption system was identified to occur at DSi concentrations of about $150 \mu \mathrm{M}$, a value also consistent with all previous kinetic studies in sponges (Reincke \& Barthel 1997, Maldonado et al. 2011, López-Acosta et al. 2016, 2018). Because the natural availability of DSi in the sponge habitat (Fig. 1) is 2 orders of magnitude below $150 \mu \mathrm{M}$, these sponges can never achieve their maximum velocity for DSi utilization. Consequently, their skeletal growth is chronically limited by low availability of DSi in their habitats. A similar kinetic limitation has also been found in all sponges previously assayed (Reincke \& Barthel 1997, Maldonado et al. 2011, López-Acosta et al. 2016, 2018) and its consequences for the skeletal growth empirically demonstrated in one case (Maldonado et al. 1999).

Our results also revealed important between-individual variability in DSi consumption rates in both $H$. perlevis and T. citrina (Fig. 4). Irrespective of the season, the smaller specimens were consuming DSi at higher rates (about 3 times on average) than the bigger ones. Yet, sponge size was responsible for only 12 and $24 \%$ of the between-individual differences in 
DSi consumption rates in $H$. perlevis and T. citrina, respectively (Fig. 5).

The statistical approaches made clear that of the 2 assayed sponges, only $1, T$. citrina, experiences seasonal kinetic changes in DSi utilization. In autumn, this sponge consumed DSi at rates $99.5 \pm 87.1 \%$ higher than in summer (Table 1, Fig. 2). These differences are, in part, explained by the availability of DSi increasing in autumn but more importantly because the values of the $K_{\mathrm{m}}$ and $V_{\max }$ parameters in the DSi consumption kinetics of this species also increase in autumn. This is the first time that such a kinetic seasonal change is demonstrated for Si users other than diatoms. The kinetic change is probably an adaptation to favor skeletal growth during those periods of the year when the natural availability of DSi is greater and enough food for the sponges still occurs in the water column. The seasonal change in temperature is not expected to be co-responsible for the seasonal shift in DSi consumption kinetics found in $T$. citrina. In the only study addressing the potential effects of temperature change on the DSi consumption rate of sponges, a non-significant effect was revealed, despite the fact that the sponge (Halichondria panicea) was exposed to the 2 extremes ( 5 and $20^{\circ} \mathrm{C}$ ) of the natural temperature range experienced by the populations over the annual cycle (Frøhlich \& Barthel 1997).

The affinity for DSi is mathematically defined as the $V_{\max } / K_{\mathrm{m}}$ quotient of the Michaelis-Menten parameters (Healey 1980). Interestingly, although the utilization of DSi by sponges is a process mediated by enzymes (Shimizu et al. 1998, Krasko et al. 2000), the seasonal kinetic change in T. citrina did not involve a substantial change in its affinity for DSi (i.e. the putative substrate of the enzymes). It was surprising that the affinity for DSi was slightly higher

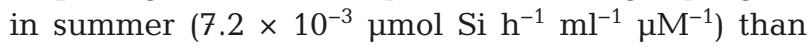

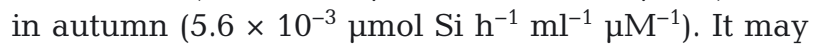
be that an increase in affinity is stimulated by a decrease in DSi availability, so that it can compensate the lowering in DSi concentration. According to our data, the increase in utilization rate appears to be achieved by increasing both $K_{\mathrm{m}}$ and $V_{\text {max }}$.

The finding that at least some siliceous sponges show seasonal kinetic changes in their utilization of DSi has several implications. First, the seasonal effect is to be considered in future $\mathrm{Si}$ budgets involving $\mathrm{DSi}$ utilization by sponges. Second, the importance of the effects will be dependent on the number of sponge species in the benthic assemblages responding to seasonality. Such knowledge can only be achieved by conducting further seasonal experiments on a greater number of species. Third, the divergence between the kinetic models in the 2 assayed seasons increased when DSi availability rose to about $30 \mu \mathrm{M}$, attaining drastic differences over $50 \mu \mathrm{M}$ (Fig. 3). If a similar kinetic shift is affecting at least some common sponge species from high latitudes and deep sea habitats, which are environments characterized by very high DSi availability, the consequences for modelling the budgets of DSi utilization in those populations may be enormous. For instance, plenty of direct and indirect evidence indicates that dense sponge aggregations established in the deep sea and on Antarctic shelves react to periodic pulses of food and dissolved nutrients entering those sponge habitats (reviewed in Maldonado et al. 2017). A simulated calculation hypothetically assuming that the siliceous sponge assemblage on the Antarctic shelf $(0.87 \times$ $10^{6} \mathrm{~km}^{2}$ ) may have a seasonal kinetic shift similar to the one detected in T. citrina can be attempted. On the Antarctic continental shelf, the DSi availability over an annual cycle ranges from mean minimum values of about $50 \mu \mathrm{M}$ to maxima of about $90 \mu \mathrm{M}$, increasing even up to $130 \mu \mathrm{M}$ in continental slope habitats (Leynaert et al. 1993, Ducklow et al. 2012). If, for this hypothetical calculation, we assume that (1) the average DSi concentration from February to September is about $60 \mu \mathrm{M}$ and for the rest of the year is about $75 \mu \mathrm{M}_{i}(2)$ the average density of siliceous sponges on the Antarctic shelf is $1.27 \mathrm{~kg}$ wet weight $\mathrm{m}^{-2}$ (Gutt et al. 2013), which by applying the morphometric conversion parameters of $T$. citrina (volume: wet weight ratio $=1.22 \mathrm{ml} \mathrm{g}^{-1}$ ) translates into an average volume of $1550 \mathrm{ml} \mathrm{m}^{-2}$; and (3) a seasonal kinetic shift similar to the one measured for $T$. citrina may affect the Antarctic sponge assemblage, we would result in a global DSi consumption for the sponge assemblage of about 1.69 $\mathrm{Tmol} \mathrm{Si}^{-1}$ only on the shelf and under the low-DSi summer conditions. Under the high-DSi (autumn) kinetics, the estimated

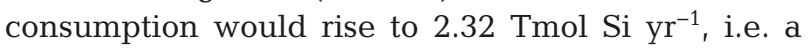
$30 \%$ increase in relative terms and a huge amount (0.63 Tmol Si) in absolute values. This simple simulation illustrates the importance of achieving a better understanding of the level at which the DSi consumption kinetics may change over the annual cycle for dominant species in sponge grounds of high latitudes, the deep sea, and any other habitat with marked periodic shifts in DSi availability.

In the Bay of Brest, the populations of the 2 assayed sponge species are responsible for the consumption of $2.50 \pm 3.21 \times 10^{6} \mathrm{~mol} \mathrm{Si} \mathrm{yr}^{-1}$ (i.e. about $70.13 \pm$ 90.19 tons $\mathrm{Si}^{-1}{ }^{-1}$ ). This value increases the net $\mathrm{BSi}$ production in the bay by about $3.2 \%$ yearly. The 
global DSi utilization in the bay had traditionally been estimated considering only the contribution of diatoms $\left(77.76 \times 10^{6} \mathrm{~mol} \mathrm{Si} \mathrm{^{-1 } )}\right.$ because no data on sponges were available until a recent study by our team, which tentatively estimated the assemblage of siliceous sponges to account collectively for about 7 to $8 \%$ of the yearly DSi utilization in the bay (LópezAcosta et al. 2018). The present study now reveals that (1) the local populations of T. citrina and H. perlevis account for about $37 \%$ of the total sponge contribution to the DSi utilization in the bay $(6.75 \times$

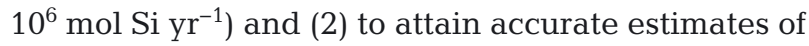
DSi consumption by sponges elsewhere, it is important to understand the potential shifts in consumption kinetics that may affect the species over the annual cycle. Subsequent studies on DSi consumption kinetics by common sponge species are required if we are to attain a more accurate quantification of the global contribution of sponges to the utilization and cycling of DSi in the ocean.

Acknowledgements. The authors thank Jacques Grall, Erwan Amice, Thierry Le Bec, and Isabelle Bihannic for their help during underwater field work. Thanks also to the Service d'Observation en Milieu Littoral (SOMLITBrest, IUEM/UBO), part of the French network for monitoring the coastal environment, for making accessible the environmental parameters of the Bay of Brest. The authors also thank the staff of the Argenton Marine Station and Aurélien Claeys for facilitating the T-ISO strain used to feed sponges. This research was supported by a grant from the Spanish Ministry of Economy and Competitiveness (CTM2015-67221-R) to M.M. and its associated FPI fellowship to M.L.-A. This study has partially benefited from funds of the European Union's Horizon 2020 research and innovation program (SponGES project, grant agreement 679849).

\section{LITERATURE CITED}

Abdo DA, Seager JW, Harvey ES, McDonald JI, Kendrick GA, Shortis MR (2006) Efficiently measuring complex sessile epibenthic organisms using a novel photogrammetric technique. J Exp Mar Biol Ecol 339:120-133

Armstrong FAJ (1965) Silicon. In: Riley JP, Skirrow G (eds) Chemical oceanography, Vol 1. Academic Press, London, p 409-432

Brunner E, Munzel U (2000) The nonparametric BehrensFisher problem: asymptotic theory and a small-sample approximation. Biom J 42:17-25

Brunner E, Domhof S, Langer F (2002) Nonparametric analysis of longitudinal data in factorial experiments. Wiley-Interscience, New York, NY

Brzezinski MA, Dumousseaud C, Krause JW, Measures CI, Nelson DM (2008) Iron and silicic acid concentrations together regulate $\mathrm{Si}$ uptake in the equatorial Pacific Ocean. Limnol Oceanogr 53:875-889

Burton JD, Liss PS (1968) Oceanic budget of dissolved silicon. Nature 220:905-906
Calvert SE (1968) Silica balance in ocean and diagenesis. Nature 219:919-920

* Chauvaud L, Jean F, Ragueneau O, Thouzeau G (2000) Long-term variation of the Bay of Brest ecosystem: benthic-pelagic coupling revisited. Mar Ecol Prog Ser 200: $35-48$

* Conley DJ, Schelske CL (1993) Potential role of sponge spicules in influencing the silicon biogeochemistry of Florida lakes. Can J Fish Aquat Sci 50:296-302

* Del Amo Y, Le Pape O, Tréguer P, Quéguiner B, Ménesguen A, Aminot A (1997a) Impacts of high-nitrate freshwater inputs on macrotidal ecosystems. I. Seasonal evolution of nutrient limitation for the diatom-dominated phytoplankton of the Bay of Brest (France). Mar Ecol Prog Ser 161:213-224

* Del Amo Y, Quéguiner B, Tréguer P, Breton H, Lampert L (1997b) Impacts of high-nitrate freshwater inputs on macrotidal ecosystems. II. Specific role of the silicic acid pump in the year-round dominance of diatoms in the Bay of Brest (France). Mar Ecol Prog Ser 161:225-237

Delmas R, Tréguer P (1985) Simulation de l'évolution de paramètres physiques, chimiques, et de la biomasse phytoplanctonlque en période printanière dans un écosystème littoral macrotidal. Oceanis 11:197-211

DeMaster DJ (2003) The diagenesis of biogenic silica: chemical transformations occurring in the water column, seabed, and crust. In: Holland HD, Turekian KK (eds) Treatise on geochemistry, Vol 7. Elsevier, Oxford, p 87-98

Ducklow H, Clarke A, Dickhut R, Doney SC and others (2012) The marine system of the western Antarctic Peninsula. In: Rogers AD, Johnston NM, Murphy EJ, Clarke A (eds) Antarctic ecosystems: an extreme environment in a changing world. Wiley-Blackwell, Chichester, p 121-159

Frøhlich H, Barthel D (1997) Silica uptake of the marine sponge Halichondria panicea in Kiel Bight. Mar Biol 128: 115-125

*Gutt J, Böhmer A, Dimmler W (2013) Antarctic sponge spicule mats shape macrobenthic diversity and act as a silicon trap. Mar Ecol Prog Ser 480:57-71

*Harriss RC (1966) Biological buffering of oceanic silica. Nature 212:275-276

Healey FP (1980) Slope of the Monod equation as an indicator of advantage in nutrient competition. Microb Ecol 5: 281-286

Koffmann LJ, Peeken I, Lochte K (2008) Iron, silicate, and light co-limitation of three Southern Ocean diatom species. Polar Biol 31:1067-1080

Javaheri N, Dries R, Burson A, Stal LJ, Sloot PMA, Kaandorp JA (2015) Temperature affects the silicate morphology in a diatom. Sci Rep 5:11652

KKrasko A, Lorenz B, Batel R, Schröder HC, Müller IM, Müller WEG (2000) Expression of silicatein and collagen genes in the marine sponge Suberites domuncula is controlled by silicate and myotrophin. Eur J Biochem 267: 4878-4887

Laruelle GG, Regnier P, Ragueneau O, Kempa M and others (2009a) Benthic-pelagic coupling and the seasonal silica cycle in the Bay of Brest (France): new insights from a coupled physical-biological model. Mar Ecol Prog Ser 385:15-32

* Laruelle GG, Roubeix V, Sferratore A, Brodherr B and others (2009b) Anthropogenic perturbations of the silicon cycle at the global scale: key role of the land-ocean transition. Global Biogeochem Cycles 23:GB4031 
Le Pape O, Del Amo Y, Menesguen A, Aminot A, Quequiner B, Treguer P (1996) Resistance of a coastal ecosystem to increasing eutrophic conditions: the Bay of Brest (France), a semi-enclosed zone of western Europe. Cont Shelf Res 16:1885-1907

Leynaert A, Nelson DM, Quéguiner B, Tréguer P (1993) The silica cycle in the Antarctic Ocean: Is the Weddell Sea atypical? Mar Ecol Prog Ser 96:1-15

López-Acosta M, Leynaert A, Maldonado M (2016) Silicon consumption in two shallow-water sponges with contrasting biological features. Limnol Oceanogr 61:2139-2150

López-Acosta M, Leynaert A, Grall J, Maldonado M (2018) Silicon consumption kinetics by marine sponges: an assessment of their role at the ecosystem level. Limnol Oceanogr (in press)

Maldonado M, Carmona MG, Uriz MJ, Cruzado A (1999) Decline in Mesozoic reef-building sponges explained by silicon limitation. Nature 401:785-788

Maldonado M, Carmona MC, Velásquez Z, Puig A, Cruzado A, López A, Young CM (2005) Siliceous sponges as a silicon sink: an overlooked aspect of benthopelagic coupling in the marine silicon cycle. Limnol Oceanogr 50: 799-809

Maldonado M, Riesgo A, Bucci A, Rutzler K (2010) Revisiting silicon budgets at a tropical continental shelf: silica standing stocks in sponges surpass those in diatoms. Limnol Oceanogr 55:2001-2010

Maldonado M, Navarro L, Grasa A, González A, Vaquerizo I (2011) Silicon uptake by sponges: a twist to understanding nutrient cycling on continental margins. Sci Rep 1: $1-30$

Maldonado M, Ribes M, van Duyl FC (2012) Nutrient fluxes through sponges: biology, budgets, and ecological implications. Adv Mar Biol 62:113-182

Maldonado M, Aguilar R, Bannister RJ, Bell JJ and others (2017) Sponge grounds as key marine habitats: a synthetic review of types, structure, functional roles, and conservation concerns. In: Rossi S, Bramanti L, Gori A, Orejas Saco del Valle C (eds) Marine animal forests: the ecology of benthic biodiversity hotspots. Springer, Cham, p 145-183

Nelson DM, Tréguer P, Brzezinski MA, Leynaert A, Qué-

Editorial responsibility: Joseph Pawlik, Wilmington, North Carolina, USA guiner B (1995) Production and dissolution of biogenic silica in the ocean: revised global estimates, comparison with regional data and relationship to biogenic sedimentation. Global Biogeochem Cycles 9:359-372

Noguchi K, Gel YR, Brunner E, Konietschke F (2012) nparLD: an R software package for the nonparametric analysis of longitudinal data in factorial experiments. J Stat Softw 50:1-23

Quéguiner B, Tréguer P (1984) Studies on the phytoplankton in the Bay of Brest (western Europe). Seasonal variations in composition, biomass and production in relation to hydrological and chemical features (1981-1982). Bot Mar 27:449-459

Ragueneau O, Quéguiner B, Tréguer P (1996) Contrast in biological responses to tidally-induced vertical mixing for two macrotidal ecosystems of western Europe. Estuar Coast Shelf Sci 42:645-665

* Ragueneau O, Tréguer P, Leynaert A, Anderson RF and others (2000) A review of the Si cycle in the modern ocean: recent progress and missing gaps in the application of biogenic opal as a paleoproductivity proxy. Global Planet Change 26:317-365

Ragueneau O, Chauvaud L, Moriceau B, Leynaert A and others (2005) Biodeposition by an invasive suspension feeder impacts the biogeochemical cycle of Si in a coastal ecosystem (Bay of Brest, France). Biogeochemistry 75: 19-41

Reincke T, Barthel D (1997) Silica uptake kinetics of Halichondria panicea in Kiel Bight. Mar Biol 129:591-593

* Rützler K, Macintyre IG (1978) Siliceous sponge spicules in coral-reef sediments. Mar Biol 49:147-159

* Shimizu K, Cha J, Stucky GD, Morse DE (1998) Silicatein $\alpha$ : cathepsin L-like protein in sponge biosilica. Proc Natl Acad Sci USA 95:6234-6238

Strickland JDH, Parsons TR (1972) A practical handbook of seawater analysis, 2nd edn. Fisheries Research Board of Canada, Ottawa

Tréguer PJ, De La Rocha CL (2013) The world ocean silica cycle. Annu Rev Mar Sci 5:477-501

* Tréguer P, Nelson DM, Van Bennekom AJ, DeMaster DJ, Leynaert A, Quéguiner B (1995) The silica balance in the world ocean: a reestimate. Science 268:375-379

Submitted: May 13, 2018; Accepted: September 5, 2018 Proofs received from author(s): September 28, 2018 